\title{
Pengaruh Suplementasi Seng Terhadap Kejadian Pneumonia pada Penyakit Jantung Bawaan Pirau Kiri ke Kanan
}

\author{
Elvi Suryati, *Agus Priyatno, * Noor Wijayahadi ${ }^{* *}$ \\ ${ }^{*}$ Departemen Ilmu Kesehatan Anak, ${ }^{* *}$ Departemen Ilmu Farmakologi Fakultas Kedokteran Universitas \\ Diponegoro/RSUP Dr.Kariadi, Semarang
}

\begin{abstract}
Latar belakang. Anak dengan penyakit jantung bawaan (PJB) pirau kiri ke kanan lebih mudah menderita pneumonia. Seng merupakan trace element yang berperan dalam sistem imunitas tubuh.

Tujuan. Membuktikan pengaruh suplementasi seng dalam mencegah kejadian pneumonia pada anak PJB pirau kiri ke kanan.

Metode. Dilakukan double blind randomized controlled trial pada anak PJB pirau kiri ke kanan usia 12-60 bulan di Poliklinik Kardiologi Anak RS dr Kariadi. Subjek penelitian dibagi 2 kelompok yang mendapat suplementasi seng $20 \mathrm{mg} /$ hari dan plasebo, pemberian selama $2 \mathrm{minggu}$, selanjutnya dipantau selama 3 bulan. Data kejadian pneumonia dikumpulkan melalui wawancara saat kontrol atau melalui telepon setiap 2 minggu selama 3 bulan. Pemeriksaan antropometri dan laboratorium dilakukan sebelum dan sesudah suplementasi. Analisis statistik dilakukan dengan uji chi-square dan Mann-Whitney.

Hasil. Subjek 40 anak dengan PJB pirau kiri ke kanan didapatkan kejadian pneumonia pada kelompok seng (5\%) lebih rendah dibanding plasebo (30\%), perbedaan ini tidak berbeda bermakna. Episode pneumonia lebih rendah pada kelompok seng 1 kali dibandingkan plasebo 1-2 kali selama 3 bulan pengamatan, tidak berbeda bermakna. Terdapat peningkatan kadar seng secara bermakna pada kelompok perlakuan dari median $57,55$ menjadi $72,42 \mathrm{mcg} / \mathrm{dL}$ dibandingkan plasebo 42,40 menjadi $52,85 \mathrm{mcg} / \mathrm{dL}$ ( $\mathrm{p}=0,002)$. Terdapat perbedaan bermakna selisih peningkatan kadar seng pada kelompok seng $20 \mathrm{mcg} / \mathrm{dL}$ dibanding plasebo $7,25 \mathrm{mcg} / \mathrm{dL}(\mathrm{p}=0,004)$. Didapatkan manfaat suplementasi seng terhadap pencegahan pneumonia dengan relative risk reduction ( $\mathrm{RRR}) 83 \%$.

Kesimpulan. Suplementasi seng menurunkan kejadian pneumonia pada anak PJB pirau kiri ke kanan.

Sari Pediatri 2014;16(4):221-8.
\end{abstract}

Kata kunci: penyakit jantung bawaan (PJB) pirau kiri ke kanan, suplementasi seng, kejadian pneumonia Alamat korespondensi:
Dr. Elvi Suryati, Sp.A. RSUD Abdul Moeloek. Jl. Dr. Rivai, Bandar
Lampung. E-mail: elvirizky@yahoo.co.id

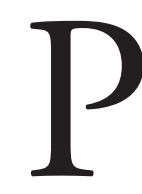

enyakit jantung bawaan (PJB) adalah penyakit dengan kelainan pada struktur jantung atau fungsi sirkulasi jantung yang dibawa dari lahir akibat adanya gangguan atau kegagalan 
perkembangan struktur jantung pada masa awal perkembangan janin. Angka kejadian penyakit jantung bawaan $8-10$ per 1000 bayi lahir hidup, bahkan dapat mencapai 75 per 1000 bayi lahir hidup. ${ }^{1}$ Pada tahun pertama kehidupan, di antara sepertiganya akan bermanifestasi sebagai kondisi kritis dan kegawatan pada bulan pertama, 50\% akan berakhir dengan kematian. ${ }^{2,3}$

Anak PJB pirau kiri ke kanan mudah terjadi infeksi saluran pernafasan berulang disebabkan oleh peningkatan aliran darah ke paru sehingga mengganggu sistem pertahanan paru. Perubahan dalam sirkulasi paru menyebabkan perubahan sistem pernafasan disertai penurunan kekebalan seluler lokal setempat yang memudahkan pasien terserang infeksi saluran pernafasan. ${ }^{4}$

Pada anak di bawah 5 tahun, infeksi saluran pernafasan bawah merupakan penyebab kematian terbanyak dan menempati porsi terbesar perawatan di rumah sakit $(30,1 \%-60,7 \%)$ dengan case fatality rate 2,7\%-12,3\%. Angka mortalitas diperkirakan 1500 per 100.000 anak di bawah 5 tahun dan 500 per 100.000 anak usia 1-4 tahun. Di Indonesia, pada anak di bawah 5 tahun, angka kesakitan pneumonia 10\%-20\% dengan kematian 6 per 1000. Manifestasi klinis pneumonia diperberat dengan adanya faktor risiko, antara lain usia di bawah 5 tahun, tingkat kepadatan rumah tinggal, polutan, nutrisi yang buruk, sosial ekonomi yang rendah, dan PJB. ${ }^{5}$ Anak PJB sering mengalami pneumonia dan akan lebih lama sembuh dibanding anak yang normal. Gagal jantung akan memperburuk keadaan tersebut, bahkan dapat berakibat kematian. Faktor yang dianggap penyebab lamanya infeksi tersebut adalah kompresi bronkus besar oleh atrium kiri atau arteri pulmonalis yang membesar akibat hipertensi pulmonalis. Atelektasis atau edem paru terjadi akibat hiperperfusi paru, hipoksemia pulmonal, dan hipoplasia jalan nafas. ${ }^{6}$

Seng dibutuhkan untuk proses percepatan pertumbuhan, menstabilkan struktur membran sel, dan mengaktifkan hormon pertumbuhan. Seng juga berperan dalam sistem kekebalan tubuh dan merupakan mediator potensial pertahanan tubuh terhadap infeksi karena memengaruhi imunitas spesifik dan non spesifik, meliputi barier tubuh seperti epitel kulit, mukosa gastrointestinal, dan saluran nafas., ${ }^{7,8}$

Tujuan peneitian ini untuk membuktikan apakah suplementasi seng elemental $20 \mathrm{mg}$ perhari selama 2 minggu dapat mencegah kejadian pneumonia pada anak PJB pirau kiri ke kanan usia 12-60 bulan yang diamati selama 3 bulan pemantauan.

\section{Metode}

Penelitian ini merupakan doubleblind randomized controlled trial (RCT) dengan rancangan uji klinis secara random menggunakan kontrol di Poliklinik Kardiologi RSUP dr. Kariadi Semarang pada periode September 2012- Agustus 2013. Penelitian ini telah mendapat persetujuan dari Komisi Etik Penelitian Kesehatan Fakultas Kedokteran Universitas Diponegoro dan RSUP Dr Kariadi Semarang No.273/EC/FK/RSDK/ 2012.

Subjek penelitian adalah anak PJB pirau kiri ke kanan yang berobat rawat jalan di Poliklinik Kardiologi RSUP dr Kariadi yang memenuhi kriteria inklusi dan eksklusi. Penelitian dibagi menjadi kelompok perlakuan dan kontrol. Kelompok perlakuan diberikan sirup seng $20 \mathrm{mg}$ setiap hari selama 2 minggu dan kelompok kontrol mendapatkan sirup plasebo. Kriteria inklusi adalah usia 12-60 bulan, menderita kelainan jantung bawaan pirau kiri ke kanan yang tidak kompleks, orang tua menyetujui anak diikutsertakan dan bersedia mentaati prosedur penelitian serta menandatangani informed consent. Kriteria eksklusi adalah timbul penyakit penyerta yang berat selama penelitian (penurunan kesadaran, gangguan hemodinamik, gangguan kardiovaskular dan respirasi), dalam kondisi imunodefisiensi (pasien penyakit keganasan, dalam terapi sitostatika, dan pasien yang sedang mendapat terapi kortikosteroid jangka panjang), tidak menderita penyakit penyerta yang berat (penurunan kesadaran, gangguan hemodinamik, gangguan kardiovaskular dan respirasi berat), menderita diare persisten, dan menderita ISPA saat penelitian dimulai. Pengambilan sampel penelitian secara consecutive sampling.

Variabel bebas penelitian adalah suplementasi seng. Variabel tergantung adalah kejadian pneumonia, episode pneumonia. Variabel perancu adalah status gizi, asupan diet mengandung seng, besar defek dan status imunisasi. Anak dikelompokkan ke dalam kelompok perlakuan dan kontrol berdasarkan random sederhana (Tabel random). Subjek total 40 anak, kelompok perlakuan 20 dan kelompok kontrol 20.

Data awal berupa data subjek, pemeriksaan antropometri, serta 4 cc sampel darah vena untuk memeriksa kadar seng serum dan darah rutin awal. 
Tabel 1. Karakteristik demografis subjek pada kedua kelompok

\begin{tabular}{|c|c|c|}
\hline \multirow{2}{*}{ Variabel } & \multicolumn{2}{|c|}{ Kelompok } \\
\hline & Perlakuan & Kontrol \\
\hline Umur (bulan) & $31,20 \pm 17,814$ & $33,50 \pm 15,619$ \\
\hline \multicolumn{3}{|l|}{ Jenis kelamin (\%) } \\
\hline Laki-laki & $7(35,0)$ & $11(55,0)$ \\
\hline Perempuan & $13(65,0)$ & $9(45,0)$ \\
\hline \multicolumn{3}{|l|}{ Pendidikan ayah (\%) } \\
\hline $\mathrm{SD}$ & $6(30,0)$ & $3(15,0)$ \\
\hline SMP & $11(55,0)$ & $6(30,0)$ \\
\hline SMA & $2(10,0)$ & $11(55,0)$ \\
\hline D3 & $1(5,0)$ & $0(0,0)$ \\
\hline \multicolumn{3}{|l|}{ Pendidikan ibu (\%) } \\
\hline SD & $5(25,0)$ & $3(15,0)$ \\
\hline SMP & $12(60,0)$ & $9(45,0)$ \\
\hline SMA & $2(10,0)$ & $8(40,0)$ \\
\hline Sarjana & $1(5,0)$ & $0(0,0)$ \\
\hline \multicolumn{3}{|l|}{ Penghasilan/bulan (\%) } \\
\hline$<500.000$ & $0(0,0)$ & $0(0,0)$ \\
\hline $500.000-<1.000 .000$ & $4(20,0)$ & $3(15,0)$ \\
\hline $1.000 .000-<1.500 .000$ & $12(60,0)$ & $14(70,0)$ \\
\hline $1.500 .000-<2.000 .000$ & $3(15,0)$ & $3(15,0)$ \\
\hline$>2.000 .000$ & $1(5,0)$ & $0(0,0)$ \\
\hline \multicolumn{3}{|l|}{ Imunisasi dasar (\%) } \\
\hline Lengkap & $19(95,0)$ & $18(90,0)$ \\
\hline Tidak lengkap & $1(5,0)$ & $2(10,0)$ \\
\hline \multicolumn{3}{|l|}{ ASI eksklusif (\%) } \\
\hline $\mathrm{Ya}$ & $14(70,0)$ & $11(55,0)$ \\
\hline Tidak & $6(30,0)$ & $9(45,0)$ \\
\hline \multicolumn{3}{|l|}{ Food Recall } \\
\hline Kalori (kkal/hari) & $1108,3 \pm 449,629$ & $1237,3 \pm 464,371$ \\
\hline Protein (gr/hari) & $88,13 \pm 171,134$ & $38,90 \pm 21,749$ \\
\hline Seng (mcg/hari) & $4,89 \pm 2,207$ & $5,61 \pm 2,796$ \\
\hline \multicolumn{3}{|l|}{ Status gizi (\%) } \\
\hline Baik & $12(60,0)$ & $15(75,0)$ \\
\hline Kurang & $4(20,0)$ & $4(20,0)$ \\
\hline Buruk & $4(20,0)$ & $1(5,0)$ \\
\hline \multicolumn{3}{|l|}{ Jenis kelainan jantung (\%) } \\
\hline VSD & $7(35,0)$ & $12(60,0)$ \\
\hline PDA & $9(45,0)$ & $3(15,0)$ \\
\hline ASD & $4(20,0)$ & $5(25,0)$ \\
\hline Besar defek jantung (mm) & $5,05 \pm 1,73$ & $6,45 \pm 2,65$ \\
\hline \multicolumn{3}{|l|}{ Derajat gagal jantung (\%) } \\
\hline Ross II & $10(50)$ & $12(60)$ \\
\hline Ross III & $10(50)$ & $8(40)$ \\
\hline \multicolumn{3}{|l|}{ Hemoglobin $(\mathrm{gr} / \mathrm{dL})$} \\
\hline Sebelum intervensi & $11,510 \pm 1,301$ & $11,525 \pm 1,068$ \\
\hline Setelah intervensi & $11,707 \pm 1,368$ & $12,179 \pm 1,491$ \\
\hline \multicolumn{3}{|l|}{ Jumlah leukosit (/mm3) } \\
\hline Sebelum intervensi & $10,501 \pm 2,783$ & $9,973 \pm 2,305$ \\
\hline \multicolumn{3}{|c|}{ 20 } \\
\hline Sebelum intervensi & $4201,5 \pm 2268,50$ & $3798,2 \pm 1434,37$ \\
\hline Setelah intervensi & $4588,0 \pm 2063,49$ & $5381,35 \pm 2585,57$ \\
\hline \multicolumn{3}{|r|}{ 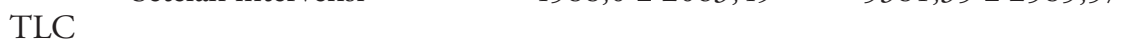 } \\
\hline Sebelum intervensi & $5095,8 \pm 2421,8$ & $6441,1 \pm 2140,1$ \\
\hline Setelah intervensi & $5193,3 \pm 2335,8$ & $2010,2 \pm 1652,7$ \\
\hline
\end{tabular}

Keterangan : VSD: ventracular septal defect, PDA: patent ductus arteriosus, ASD: atrial septal defect 
Orang tua subjek penelitian diberikan dua botol sirup seng $(100 \mathrm{ml})$ pada kelompok perlakuan dan sirup plasebo pada kelompok kontrol beserta sendok takar untuk diminumkan ke anak mereka ( $5 \mathrm{ml}=1$ sendok takar) setiap hari. Pemantauan meliputi kejadian pneumonia, sisa sirup seng, panjang badan, berat badan, dilakukan setiap 2 minggu melalui telepon dan saat datang kontrol ke Poliklinik Jantung. Akhir penelitian di bulan ketiga dilakukan pengambilan 4 cc darah vena untuk melihat kadar seng serum dan darah rutin setelah suplementasi. Pemeriksaan kadar seng serum ini dilakukan di Laboratorium GAKI FK UNDIP RS Dr. Kariadi, Semarang. Analisis statistik dengan analisis deskriptif, uji independent $t$ test atau Mann-whitney. Uji beda untuk membandingkan kadar seng sebelum dan sesudah intervensi pada kedua kelompok dengan menggunakan uji t test berpasangan. RRR (relative reduction risk) digunakan untuk menilai manfaat suplementasi seng. Analisis data dilakukan dengan program komputer.

\section{Hasil}

Tabel 1 menunjukkan karakteristik dari kedua kelompok tidak berbeda bermakna $(p>0,05)$. Faktor perancu-besar defek, derajat gagal jantung, status gizi, dan asupan makanan yang mengandung senghasil uji beda didapatkan tidak berbeda bermakna $(p>0,05)$ sehingga tidak perlu dilanjutkan dengan uji multivariat.

Tabel 2 menunjukkan kadar seng serum sebelum intervensi pada kedua kelompok memiliki median rendah, kelompok perlakuan $57,55 \mathrm{mcg} / \mathrm{dL}$ lebih tinggi dibanding kelompok kontrol $42,40 \mathrm{mcg} /$ dL. Kadar seng normal serum $80-110 \mathrm{mcg} / \mathrm{dL} .{ }^{9} \mathrm{Uji}$ statistik menunjukkan terdapat perbedaan bermakna pada kedua kelompok sebelum dilakukan intervensi $(\mathrm{p}=0,000)$. Setelah intervensi didapatkan peningkatan kadar seng serum pada kelompok perlakuan 72,42 $\mathrm{mcg} / \mathrm{dL}$ dibanding kelompok kontrol 52,85 mcg/ $\mathrm{dL}(\mathrm{p}=0,002)$. Selanjutnya, dilakukan analisis untuk mengetahui perbedaan perubahan kadar seng pada kedua kelompok setelah diberikan suplementasi. Hasil analisis delta seng pada kedua kelompok didapatkan median pada kelompok perlakuan $20 \mathrm{mcg} / \mathrm{dL}$, kelompok kontrol 7,25 mcg/dL, terdapat perbedaan bermakna delta seng kedua kelompok $(\mathrm{p}=0,004)$.

Hasil analisis perbedaan skor WHZ, HAZ, dan WAZ pada kelompok perlakuan didapatkan perbedaan bermakna sebelum dan setelah intervensi. Terdapat perbaikan status pertumbuhan pada kelompok perlakuan setelah suplementasi seng dilihat dari skor WHZ, HAZ, dan WAZ dibandingkan kelompok kontrol.

Pada Tabel 3, persentase menunjukkan 15\% kejadian diare pada kelompok perlakuan dan 55\% kelompok kontrol, terdapat perbedaan bermakna $(\mathrm{p}=0,008)$ kejadian diare pada kedua kelompok. Tabel ini juga menunjukkan bahwa seng dapat mencegah dan menurunkan kejadian diare dengan OR 0,144 (IK95\% 0,032-0,654).

Tabel 4 menunjukkan kejadian pneumonia pada kelompok perlakuan (5\%) lebih rendah dibandingkan

Tabel 2. Uji beda berpasangan kadar seng sebelum dan sesudah intervensi pada kedua kelompok penelitian

\begin{tabular}{lccc}
\hline $\begin{array}{l}\text { Kadar seng } \\
(\mathrm{mcg} / \mathrm{dL})\end{array}$ & $\begin{array}{c}\text { Pre } \\
\text { Median (min-max })\end{array}$ & $\begin{array}{c}\text { Post } \\
\text { Median (min-max })\end{array}$ & $\begin{array}{c}\mathrm{p} \\
\text { (berpasangan) }\end{array}$ \\
\hline Perlakuan & $57,55(40,37-88,70)$ & $72,42(58,60-138,00)$ & $0,000^{1}$ \\
Kontrol & $42,40(33,23-103,7)$ & $52,85(37,45-115,97)$ & $0,002^{1}$ \\
\hline p (tidak berpasangan) & $0,002^{2}$ & $0,000^{2}$ & \\
\hline
\end{tabular}

Keterangan : ${ }^{1}$ Uji Wilcoxon, ${ }^{2}$ Uji Mann Whitney

Tabel 3. Perbedaan kejadian diare pada kedua kelompok penelitian

\begin{tabular}{|c|c|c|c|c|c|c|}
\hline \multirow{2}{*}{ Diare } & \multicolumn{2}{|c|}{ Kelompok } & \multirow[b]{2}{*}{$\mathrm{p}$} & \multirow{2}{*}{ OR } & \multicolumn{2}{|c|}{ IK95\% } \\
\hline & Perlakuan & Kontrol & & & Bawah & Atas \\
\hline Ya & $3(15,0 \%)$ & $11(55,0 \%)$ & $0,008^{1}$ & 0,144 & 0,032 & 0,654 \\
\hline Tidak & $17(85,0 \%)$ & $9(45,0 \%)$ & & & & \\
\hline
\end{tabular}

Keterangan: uji Pearson chi-square 
kelompok kontrol $(30 \%)$, tetapi tidak berbeda bermakna ( $\mathrm{p}=0,091)$. Relative risk reduction ( $R R R)$ $83 \%$ menunjukkan bahwa suplementasi seng memiliki manfaat klinis untuk mencegah terjadinya pneumonia pada anak PJB pirau kiri ke kanan (RRR $\geq 25 \%$ ). Mencegah kejadian sakit pneumonia pada 1 anak PJB cukup dengan memberikan suplementasi seng pada 4 anak (NNT: 4). ${ }^{10}$ Sementara hasil analisis episode pneumonia pada kelompok perlakuan 1 kali dan kelompok kontrol 1-2 kali selama pemantauan 3 bulan, tetapi tidak berbeda bermakna $(\mathrm{p}=0,386)$.

Tabel 4. Perbedaan kejadian pneumonia pada kedua kelompok penelitian

\begin{tabular}{lccc}
\hline \multirow{2}{*}{ Pneumonia } & \multicolumn{2}{c}{ Kelompok n (\%) } & \multirow{2}{*}{ p } \\
\cline { 2 - 3 } & Perlakuan & Kontrol & \multirow{2}{*}{0,091} \\
\hline Ya & $1(5)$ & $6(30)$ & \\
Tidak & $19(95)$ & $14(70)$ & \\
\hline
\end{tabular}

Keterangan: Fisher's Exact Test

Absolute risk reduction (ARR): 0,25, relative risk reduction (RRR):0,83, numbers needed to treat (NNT): 4 .

\section{Pembahasan}

Seng merupakan mikronutrien yang berperan dalam produksi hormon pertumbuhan (growth hormon/ GH) untuk mengaktifkan dan memulai sintesis hormon pertumbuhan sehingga berperan dalam memperbaiki status pertumbuhan. ${ }^{11}$ Pada kedua kelompok, pemantauan pertumbuhan menunjukkan peningkatan skor WHZ, HAZ, dan WAZ pada kelompok perlakuan dibandingkan kontrol.

Analisis food recall asupan kalori kelompok perlakuan lebih rendah dibanding kelompok kontrol. Asupan protein kelompok perlakuan didapatkan lebih tinggi dibanding kelompok kontrol. Asupan protein yang tinggi dapat berpengaruh terhadap kadar seng serum. Protein hewani merupakan sumber seng utama dengan absorbsi yang baik. Asupan seng dari makanan kelompok perlakuan lebih rendah dibandingkan kelompok kontrol. Hal tersebut menyebabkan peningkatan kadar seng serum kelompok kontrol, meskipun tidak mendapat suplementasi seng, belum mencapai kadar normal serum. Hasil pemantauan akseptabilitas suplementasi seng yang diberikan kelompok perlakuan didapatkan 17 subjek menghabiskan 75 cc (100\%) dan 3 menghabiskan 60 cc $(80 \%)$ sirup seng. Kadar seng serum selain dipengaruhi suplementasi seng yang diberikan juga dipengaruhi asupan diet yang mengandung protein hewani dan seng, sementara diet tinggi fitat dapat menghambat absorbsi seng.

Anak PJB pirau kiri ke kanan dengan gagal jantung sering mengalami malnutrisi disebabkan intake kalori makanan yang rendah dan peningkatan kebutuhan kalori. Hal tersebut berkaitan dengan adanya kesulitan makan akibat takipnea, kelelahan, ISPA berulang sehingga terjadi anoreksia. Penurunan aliran darah splanik menyebabkan terjadinya edema pada dinding dan mukosa usus sehingga terjadi malabsorbsi. ${ }^{12,13} \mathrm{Hal}$ tersebut merupakan penyebab terjadinya malnutrisi dan defisiensi seng pada anak PJB pirau kiri ke kanan.

Asupan gizi anak berpengaruh terhadap status gizi dan risiko terjadinya penyakit infeksi. Asupan zat gizi, baik makro maupun mikro, berpengaruh terhadap sistem imun anak. Salah satu zat gizi makro yang berpengaruh terhadap sistem imun adalah protein. Seng merupakan mikronutrien penting dalam sistem kekebalan tubuh. Seng juga merupakan mediator potensial pertahanan tubuh terhadap infeksi dan memengaruhi imunitas spesifik dan non spesifik, meliputi barier tubuh seperti epitel kulit, mukosa gastrointestinal, dan saluran nafas. ${ }^{7,8}$ Selain itu, seng berpengaruh terhadap limfosit dan fungsi fagositosis. ${ }^{14}$ Pada anak usia 1-5 tahun, kebutuhan seng perhari antara 3-5 mg/ hari. Asupan seng makanan perhari pada kelompok perlakuan 4,8 mg/hari, pada kontrol 5,6 mg/ hari. Faktor yang dapat memengaruhi kadar seng serum, seperti infeksi berulang, stres akibat kegagalan organ (gagal jantung) dapat meningkatkan kebutuhan seng. Sementara itu, gangguan gastrointestinal (diare) dapat meningkatkan kehilangan seng melalui feses sehingga terjadi defisiensi.

Kadar seng serum pada subjek penelitian ini masih di bawah normal $(<80 \mathrm{mcg} / \mathrm{dL})$. Selama penelitian tidak didapatkan gejala toksisitas. Setelah pemberian suplementasi seng selama 15 hari didapatkan peningkatan kadar seng kelompok perlakuan, nilai median $72,42 \mathrm{mcg} / \mathrm{dL}$ mendekati nilai normal (80$110 \mathrm{mcg} / \mathrm{dL}$ ). Sementara itu, nilai median kadar seng kelompok kontrol tetap di bawah nilai normal $(52,85$ $\mathrm{mcg} / \mathrm{dL}$ ). Populasi yang mengalami defisiensi seng $21 \%$ disebabkan intake makanan yang tidak adekuat. Pada anak, penyebab utama terjadinya defisiensi seng karena kualitas diet yang rendah serta peningkatan kehilangan seng lewat feses yang disebabkan adanya infeksi gastrointestinal (diare). ${ }^{15,16}$ Penelitian meta analisis dari 
17 penelitian RCT suplementasi seng selama $\geq 3$ bulan pada anak $<5$ tahun, mendapatkan hasil suplementasi seng menurunkan frekuensi dan keparahan penyakit diare dan ISPA. ${ }^{17}$

Angka kejadian diare lebih rendah kelompok perlakuan (15\%) dibandingkan kelompok kontrol (55\%). Seng berpengaruh dalam mencegah kejadian diare pada kelompok perlakuan. Hal tersebut sesuai dengan penelitian WHO yang menunjukkan bahwa pemberian suplementasi seng 10-20 mg perhari selama 10-14 hari pada balita dapat menurunkan insiden diare selama 2-3 bulan. ${ }^{18}$ Konsentrasi seng plasma dapat menurun karena pengaruh beberapa faktor, selain asupan yang kurang, adanya infeksi, stres organ, penyakit gastrointestinal (diare), hipoalbuminemia. ${ }^{16}$

Pemantauan selama 3 bulan setelah diberikan suplementasi seng selama 2 minggu didapatkan kejadian pneumonia pada kelompok perlakuan lebih rendah dibandingkan kelompok kontrol. Episode pneumonia selama 3 bulan pengamatan didapatkan lebih rendah pada kelompok perlakuan. Besarnya defek dan derajat gagal jantung sangat berpengaruh terhadap tingkat kerentanan untuk menderita pneumonia.

Penelitian meta-analisis pada beberapa penelitian RCT suplementasi seng pada anak $<5$ tahun selama 3 bulan didapatkan angka kejadian pneumonia menurun pada kelompok seng. ${ }^{19}$ Penelitian di Vietnam, India, Jamaica, Peru, dan India dilaporkan pemberian suplementasi seng pada anak usia 4-36 bulan dapat menurunkan episode ISPA bawah $41 \% .{ }^{20}$ Penelitian di daerah urban, New Delhi, dengan pemberian suplementasi seng $20 \mathrm{mg}$ setiap hari selama 4 bulan, pada anak usia 6-36 bulan (2482 orang), didapatkan penurunan insiden pneumonia 2,5\% pada kelompok yang mendapat suplementasi Seng. ${ }^{21}$ Penelitian meta -analisis lain dari beberapa penelitian RCT pada anak usia $<5$ tahun, dengan pemberian suplementasi seng selama $\geq 2$ minggu, didapatkan penurunan kejadian diare dan pneumonia. ${ }^{22}$

Penelitian RCT di India terhadap 609 anak usia 6-35 bulan (298 kelompok seng dan 311 kelompok plasebo), dengan pemberian suplementasi seng 10 mg selama 6 bulan, didapatkan penurunan kejadian pneumonia $45 \%$ pada kelompok seng. Penelitian ini juga mendapatkan bahwa episode pneumonia lebih rendah pada kelompok yang mendapat suplementasi seng dibandingkan plasebo. ${ }^{23}$ Penelitian meta-analisis terhadap 6 penelitian RCT di negara berkembang tentang pengaruh suplementasi seng terhadap pencegahan pneumonia pada anak usia 2-59 bulan (7850 anak), didapatkan penurunan insiden pneumonia $13 \% .^{24}$

Tidak semua penelitian melaporkan seng memberikan manfaat dalam menurunkan insiden pneumonia. Penelitian RCT di Nepal, pada anak usia 2 bulan - 5 tahun (2599 anak), diberikan suplementasi seng 10 $\mathrm{mg} /$ hari pada usia 2-11 bulan dan $20 \mathrm{mg} /$ hari usia 12-59 bulan selama 14 hari. Selanjutnya, pemantauan dilakukan selama 6 bulan kejadian pneumonia dan diare. Hasil penelitian tidak mendapatkan penurunan kejadian pneumonia dan diare. ${ }^{25}$ Demikian pula penelitian RCT di Salvador, Brazil, pada anak usia 6-48 bulan diberikan suplementasi seng selama 90 hari. Hasil pemantauan didapatkan insiden pneumonia yang tinggi pada kedua kelompok, kelompok seng $60 \%$ dan $48,5 \%$ pada kelompok kontrol. ${ }^{26}$ Faktor yang meenyebabkan pemberian suplementasi seng tidak berpengaruh terhadap penurunan morbiditas pneumonia pada penelitian ini, antara lain karena lamanya waktu pemberian suplementasi seng, perubahan cuaca, polusi udara, dan klasifikasi yang kurang spesifik dalam penentuan kriteria pneumonia. ${ }^{26}$

Respiratory syncytial virus (RSV) merupakan patogen penting yang berkontribusi besar untuk menimbulkan ISPA bawah pada populasi anak dengan PJB. Infeksi RSV dapat meningkatkan komplikasi jantung yang menyebabkan anak tersebut harus menjalani perawatan di rumah sakit. ${ }^{29}$ Suplementasi seng dapat meningkatkan fungsi imunitas seluler maupun humoral sehingga diharapkan kejadian pneumonia pada anak PJB pirau kiri ke kanan berkurang. ${ }^{21}$

Penelitian sebelumnya melaporkan bahwa pemberian suplementasi seng pada anak di negara berkembang secara bermakna menurunkan prevalensi ISPA bawah serta memperpendek durasi sakit. Pengaruh pemberian seng dalam menurunkan durasi dan keparahan sakit ISPA, melalui mekanisme efek seng sebagai antioksidan dan anti-inflamasi. ${ }^{30,31}$ Sama dengan penelitian lain yang menyatakan bahwa pemberian suplementasi seng dapat menghambat kemampuan replikasi dari virus RSV, hasil penelitian secara invitro mendapatkan bahwa seng menghambat replikasi RSV sejak preinkubasi, absorpsi, penetrasi, dan ekskresi. ${ }^{32}$

Defisiensi seng dihubungkan dengan atrofi timus, limfopenia, dan penurunan respon imun termediasi sel 
dan antibodi. Sel epitel timus menghasilkan timulin yang merupakan hormon yang berperan dalam adhesi, migrasi, maturasi, dan peningkatan fungsi sel T. Timulin bergantung pada seng untuk aktivitas biologis yang meliputi induksi perkembangan sel $\mathrm{T}$ dan efek anti-inflamasi. Efek seng sebagai anti oksidan dan anti-inflamasi berpotensi dan berperan penting dalam patogenesis pneumonia, dengan adanya kerusakan membran mukosa dan kongesti akibat eksudat inflamasi. Seng dapat menurunkan akumulasi spesies oksigen reaktif saat infeksi yang dapat menyebabkan kerusakan jaringan, seng berperan sebagai growth agent regenerasi sel epitel saluran nafas yang diperlukan untuk perbaikan jaringan paru yang rusak akibat pneumonia. $^{33}$

Penurunan kejadian pneumonia pada kelompok perlakuan lebih rendah dibandingkan kelompok kontrol. Kemungkinan disebabkan waktu pemberian suplementasi seng yang kurang lama dan jumlah sampel yang kurang banyak meski telah memenuhi syarat jumlah sampel minimal.

Keterbatasan penelitian ini adalah pemberian suplementasi seng hanya diberikan selama 2 minggu karena adanya keterbatasan waktu. Disamping itu, terdapat perbedaan kadar seng pada kedua kelompok sebelum dilakukan intervensi. Pada pemantauan setiap 2 minggu dilakukan selama 3 bulan melalui telepon atau saat kontrol ke poliklinik kardiologi anak dan tidak dilakukan kunjungan rumah disebabkan sebagian besar subjek berasal dari daerah luar kota Semarang. Pencantuman kode A dan B pada botol sirup seng dan plasebo dapat menyebabkan bias pengukuran.

\section{Kesimpulan}

Pemberian suplementasi seng setiap hari selama 2 minggu menurunkan kejadian pneumonia pada anak PJB pirau kiri ke kanan. Sementara itu, pemberian suplementasi seng tidak berpengaruh terhadap episode sakit pneumonia pada anak PJB pirau kiri ke kanan. Terdapat peningkatan kadar seng serum setelah pemberian suplementasi seng. Suplementasi seng bermanfaat untuk menurunkan kejadian pneumonia pada anak PJB pirau kiri ke kanan. Disarankan untuk memberikan suplementasi seng pada anak PJB pirau kiri ke kanan sehingga dapat memperbaiki kadar seng serum dan status imunitas tubuh.

\section{Daftar pustaka}

1. Priyatno A. Deteksi dini penyakit jantung bawaan kritis pada neonatus. Dalam: Riswanto S, Susanto R, penyunting. Pendekatan klinis jantung, paru, infeksi dan hematologi. Salatiga;2007.h.25-30.

2. Soeroso S, Sastrosoebroto H. Penyakit jantung bawaan non sianotik. Buku ajar kardiologi anak. Dalam: Sastroasmoro S, Madiyono B, penyunting. Jakarta: Balai Penerbit;1994.h.191-233.

3. Bedard E, Shore DF, Gatzoulis MA. Adult congenital heart disease overview. Brit Med Bull 2008;85:151-80.

4. Wilar R, Wantania JM. Beberapa faktor yang berhubungan dengan episode infeksi saluran pernafasan akut pada anak dengan penyakit jantung bawaan. Sari Pediatri 2006;8:154-8.

5. Healy F, Hanna BD, Zinman R. Pulmonary complications of congenital heart disease. Paediatr Res Rev 2011;30:1-6.

6. Afandi NS. Infeksi saluran pernafasan akut pada anak dengan penyakit jantung bawaan. Dalam:Putra ST, Roebiono PS, Rahayuningsih SE, Wulandari DA, penyunting. Towards competence-based practice in pediatric cardiology. Bandung: Indonesian Society of Pediatric Cardiology;2007.h.71-7.

7. Dardenne M. Seng and immune fuction. Eur J Cli Nutr 2002;56:20-3.

8. Cunningham-Rundles $S$. Seng and immune function. IZA 2005:1-4

9. Dijkhuizen M, Wieringa F. Vitamin A, iron and Seng deficiency in Indonesia. J Nutr Pediatr 2001;34:102-7

10. Sastroasmoro S. Telaah kritis makalah kedokteran. Dalam: Sastroasmoro S, Ismael S, penyunting. Dasardasar metodologi penelitian klinis. Edisi ke-4. Jakarta: Sagung Seto;2011.h.469-79

11. Agustian L, Sembiring T, Ariani A. Peran zinkum terhadap pertumbuhan anak. Sari Pediatri 2009;11:244-9.

12. Sjarif DR, Anggriawan AL, Putra ST, Djer MM. Anthropeometric profiles of children with congenital heart disease. Med J Indones 2011;20:40-5.

13. Tokel K, Azak E, Ayabakan C, Varan B, Aslamaci S, Mercan S. Somatic growth after corrective surgery for congenital heart disease. Turk J Pediatr 2010;52:58-67.

14. Schrimshaw NS, SanGiovanni JP. Synergism of nutrition, infection and immunity: an overview. Am J Clin Nutr 1997;66:464-77.

15. Fontaine O. Effect of seng supplementation on clinical course of acute diarrhoea. J Health Popul Nutr 2001;19:339-46. 
16. Hotz C, Brown KH. Assessment of the risk of seng deficiency in populations and options for its control. Food Nutr Bull 2004;25:S99-200.

17. Aggarwal R, Sentz J, Miller MA. Role of seng administration in prevention of childhood diarrhea and respiratory illnesses: a meta-analysis. AAP 2007;119: 1120-30.

18. WHO. Essential concepts concerning diarrhoea. Guidelines for policy makers and programme managers: The treatment of diarroea. Geneva: Switzerland. WHO;2006.

19. Roth D, Richard S, Black R. Seng supplementation for the prevention of acute lower respiratory infection in children in developing countries: meta-analysis and meta-regression of randomized trials. IJE 2010;39:795-808.

20. Bhatnagar $S$, Natchu U. Seng in child healt and disease. Indian J Pediatr 2004;71:991-5.

21. Bhandari N, Bahl R, Teneja S, Strand T, Molbak K, Ulvik R. Effect of routine Seng supplementation on pneumonia in children aged 6 manths to 3 years: randomized controlled trial in urban slum. BMJ 2002;324.

22. Bhutta ZA, Black RE, Brown KH, Gardner JM, Gore $S$, Hidayat A. Prevention of diarrhea and pneumonia by Seng supplementation in children in developing countries: Pooled analysis of randomized controlled trials. J Pediatr 1999;135:689-97.

23. Sazawal S, Black R, Jalla S, Mazundar S, Sinha A, Bhan $M$. Seng supplementation reduces the incidensce of acute lower respiratory infection in infants and preschool children: a double-blind, controlled trial. Pediatrics 1998;102:1-5.

24. Lassi Z, Haider B, Bhutta Z. Seng supplementation for the prevention of pneumonia in children aged 2 months to 59 months. Cochrane Database Syst Rev
2010;12:193-9.

25. Chandyo RK, Shrestha PS, Valentiner-Branth P, Mathisen M, Basnet S, Ulak M. Two weeka of Seng administration to Nepalese children with pneumonia does not reduce the incidence of pneumonia or diarrhea during the next six months. J Nutr 2010;140:1677-82.

26. Sampaio D, de-Mattos A, Ribeiro T, de-Leite M, Cole C, Costa-Ribeiro H. Seng and other micronutrients supplementations through the use of sprinkles: impact on the occurence of diarrhea and respiratory infections in institutionalized children. J Ped 2013;89:286-93.

27. Yau KI, Fang LJ, Wu MH. Lung mechanics in infants with left-to-right shunt congenital heart disease. Pediatric Pulmonology 1996:42-7.

28. Owayed A, Campbell D, Wang E. Underlying causes of recurrent pneumonia in children. Arch Pediatr Adolesc Med 2000;154:190-5.

29. Geskey J, Cyran S. Managing the morbidity associated with respiratory viral infections in children with congenital heart disease. Int J Paedtr 2012;20:1-8.

30. Prasad A, Fitzgerald J, Bao B, Beck F, Chandrasekar H. Duration of symptoms and plasma cytokine levels in patients with the common cold treated with Seng acetate. Ann Intern Med 2000;133:245-52.

31. Vakili R, Vahedian M, Khodael G, Mahmoudi M. Effects of seng supplementation in occurrence and duration of common cold in school aged children during cold season: a double-blind placebo-controlled trial. Iran J Pediatr 2009; 19:376-80.

32. Suara R, Crowe J. Effect of Seng salts on respiratory syncytial virus replication. ASM J 2004;48:783-90.

33. Ngom P, Howie S, Ota M, Prentice A. The potential role and possible immunological mechanisms of zinc adjuntive therapy for severe pneumonia in children. Open Immunol J 2011;4:1-10. 